\title{
PENGARUH GAYA BELAJAR TERHADAP PRESTASI BELAJAR MATA PELAJARAN MENGGAMBAR DENGAN PERANGKAT LUNAK KELAS XI TEKNIK GAMBAR BANGUNAN DI SMK NEGERI 6 BEKASI
}

\author{
Satria Nurachmat ${ }^{1}$, Riyan Arthur ${ }^{2}$, Rosmawita Saleh ${ }^{3}$ \\ ${ }^{1}$ Alumni PTB FT UNJ, satrianurachmat09@gmail.com \\ 2Dosen PTB FT UNJ, arthur@unj.ac.id \\ ${ }^{3}$ Dosen PTB FT UNJ, rosmawitasaleh@unj.ac.id
}

\begin{abstract}
Abstrak
Penelitian ini bertujuan untuk mengetahui pengaruh gaya belajar terhadap prestasi belajar mata pelajaran menggambar dengan perangkat lunak pada materi penggunaan sistem toolbars dalam penggambaran denah siswa kelas XI Teknik Gambar Bangunan di SMK Negeri 6 Bekasi.

Penelitian ini dilaksanakan pada bulan Agustus 2017. Sampel dalam penelitian ini adalah seluruh siswa kelas XI Teknik Gambar Bangunan yang berjumlah 50 siswa. Dalam penelitian ini menggunakan metode survey dengan desain deskriptif korelasional. Teknik pengumpulan data yang digunakan adalah tes soal uraian, teknik analisis data yang digunakan untuk menguji hipotesis adalah teknik analisis regresi.

Hasil penelitian menunjukkan bahwa terdapat pengaruh yang positif dan signifikan gaya belajar terhadap prestasi belajar mata pelajaran menggambar dengan perangkat lunak siswa kelas XI Teknik Gambar Bangunan di SMK Negeri 6 Bekasi. Persamaan regresi yang diperoleh $\mathrm{F}_{\text {hitung }}=7,373>\mathrm{F}_{\text {tabel }}=0,814$ pada taraf signifikan $0,05(5 \%)$. Penggunaan gaya belajar terbimbing memberikan kontribusi terhadap prestasi belajar mata pelajaran menggambar dengan perangkat lunak pada materi penggunaan sistem toolbars dalam penggambaran denah didapatkan rata-rata nilai sebesar 86,32.

Kata kunci : Gaya Belajar, Menggambar dengan perangkat lunak, Prestasi Belajar.
\end{abstract}

\section{THE INFLUENCE OF LEARNING STYLES OF LEARNING ACHIEVEMENT OF THE SUBJECT OF DRA WING WITH SOFTWARE CLASS XI BUILDING DRA WING TECHNIQUE AT SMK NEGERI 6 BEKASI}

\author{
Satria Nurachmat ${ }^{1}$, Riyan Arthur ${ }^{2}$, Rosmawita Saleh ${ }^{3}$ \\ ${ }^{1}$ Alumni PTB FT UNJ, satrianurachmat09@gmail.com \\ ${ }^{2}$ Lecturer of PTB FT UNJ, arthur@,unj.ac.id \\ ${ }^{3}$ Lecturer of PTB FT UNJ, rosmawitasaleb@,unj.ac.id
}

\begin{abstract}
The research purpose to know the connection and how the impact of way of learning for drawing lesson achievement in software material use toolbars system in drawing plan on SMKN 6 Bekasi.

The subject of the research are all of students on XI class building drawing engineering on SMKN 6 Bekasi about 60 students. The method is surveying with corelative design perspective the analysis method for testing the bypothesis is regression analysis.

The result show that (1) Ther is an impact positive and significant the impact of way of learning for drawing lesson achievement in software on SMKN 6 Bekasi. The regression result Fhit $=7,373>$ Ftab $=$ 0,814 on significant 0,05 (5\%). Regression coefficient Fbit $=3,530>$ Ftab $=1,667$ on significant 0,05
\end{abstract}


(5\%), The use of guided learning styles contributes to the learning achievement of drawing subjects with software on the use of toolbars in the depiction of the floor plan obtained an average value of 86.32

Keywords : The way of learning, Study achievement.

\section{Pendahuluan}

Dalam Dalam suatu lembaga pendidikan, prestasi belajar merupakan indikator yang penting untuk mengukur keberhasilan dari proses belajar. Dalam proses pembelajaran tidak dapat dilepaskan dengan penggunaan gaya belajar siswa. Berbagai jenis dari penggunaan gaya belajar dalam proses pembelajaran turut mendukung optimalisasi terhadap prestasi belajar yang didapatkan. Dalam proses pembelajaran, pencapaian serta pengembangan materi atau bahan ajar dapat melalui berbagai cara, salah satunya adalah penggunaan gaya belajar terbimbing pada proses pembelajaran.

Dengan mengoptimalkan penggunaan belajar terbimbing, tentu memudahkan siswa dalam proses pembelajaran. Penggunaan gaya belajar terbimbing berperan dalam suatu proses belajar mengajar, hal tersebut dapat mempermudah penalaran siswa dalam proses pembelajaran dan membantu siswa dalam memahami serta menguasai mata pelajaran. Selain itu, memudahkan dalam menerima informasi ataupun pengetahuan baru sehingga dapat meningkatkan pencapaian prestasi belajarnya. SMK Negeri 6 Bekasi merupakan salah satu Sekolah Menengah Kejuruan yang berkewajiban untuk menciptakan lulusan yang memiliki kemampuan, keterampilan serta ahli dalam bidang tertentu. SMK Negeri 6 Bekasi memiliki 4 kompetensi ahli bidang kejuruan diantaranya Teknik Gambar Bangunan, Teknik Mesin Pendingin dan Akutansi. Salah satu mata pelajaran di SMK Negeri 6 Bekasi untuk kompetensi ahli bidang Teknik Gambar Bangunan adalah menggambar dengan perangkat lunak yang merupakan mata pelajaran kejuruan yang wajib diajarkan kepada siswa. Maka dari itu siswa diharapkan dapat mengerti dan menguasai mata pelajaran ini dengan baik. Adanya program remedial yang diselenggarakan menjadi tolak ukur masih kurang baiknya prestasi belajar siswa tersebut. Banyak faktor-faktor yang mempengaruhi mengapa prestasi belajar siswa tersebut kurang baik berasal dari faktor lingkungan dan faktor diri sendiri. Salah satu faktor yang berasal dari diri sendiri adalah penggunaan gaya belajar dalam proses belajarnya.

Selama ini pembelajaran mata pelajaran menggambar dengan perangkat lunak, guru menggunakan metode gaya belajar mandiri yang membuat siswa kurang memahami serta keterbatasan dalam penggunaan perangkat lunak ketika proses pembelajaran dilakukan. Untuk itu perlu adanya perubahan di dalam penggunaan gaya belajar pada siswa guna meningkatkan prestasi belajar.

\section{Identifikasi masalah}

Berdasarkan pada latar belakang masalah yang diuraikan diatas, maka teridentifikasi sebagai berikut:

1. Bagaimana Bagaimana mengoptimalkan gaya belajar dalam prestasi belajar mata pelajaran menggambar dengan perangkat lunak kelas XI di SMK Negeri 6 Bekasi?

2. Apakah terdapat pengaruh yang signifikan gaya belajar siswa kelas XI di SMK Negeri 6 Bekasi terhadap prestasi belajar mata pelajaran menggambar dengan perangkat lunak

3. Bagaimana penggunaan gaya belajar terbimbing siswa kelas XI di SMK Negeri 6 Bekasi terhadap prestasi belajar mata pelajaran menggambar dengan perangkat lunak? 


\section{Pembatasan Masalah}

Pembatasan masalah dimaksudkan untuk dapat membahas masalah menjadi terfokus dan terarah pada sasaran yang diinginkan. Penelitian ini memiliki batasan masalah sebagai berikut:

1. Penelitian ini difokuskan untuk mengetahui pengaruh gaya belajar siswa SMK Negeri 6 Bekasi terhadap prestasi belajar mata pelajaran menggambar dengan perangkat lunak.

2. Penelitian ini hanya mengambil $1 \mathrm{KD}$ yaitu penggunaan sistem toolbars dalam penggambaran denah.

3. Sampel dalam penelitian ini hanya meneliti kelas XI Teknik Gambar Bangunan di SMK Negeri 6 Bekasi.

\section{Perumusan Masalah}

Berdasarkan latar belakang, identifikasi masalah, dan pembatasan masalah, dapat disusun suatu perumusan masalah, yaitu: Adakah pengaruh gaya belajar terhadap prestasi belajar mata pelajaran menggambar dengan perangkat lunak kelas XI Teknik Gambar Bangunan di SMK Negeri 6 Bekasi?

\section{Tujuan Penelitian} adalah:

Adapun tujuan dari penelitian ini

1. Untuk mengetahui pengaruh gaya belajar terhadap prestasi belajar mata pelajaran menggambar dengan perangkat lunak .

2. Untuk mengetahui bahwa setelah menggunakan gaya belajar terbimbing ini prestasi belajar akan meningkat atau tidak.

3. Untuk mengetahui berapa hasil rata rata nilai mata pelajaran menggambar dengan perangkat lunak pada materi penggunaan sistem toolbars dalam penggambaran denah dengan penggunaan gaya belajar terbimbing dan gaya belajar mandiri.
Gaya belajar menurut Uno (2008:180) yaitu setiap siswa memiliki cara yang berbeda dalam memahami dan menyerap suatu informasi yang didapatkan. Ada siswa yang cepat dalam memahami dan menyerap informasi tersebut, tetapi ada pula yang sedang bahkan sangat lambat. Perbedaan tersebut dapat dipengaruhi oleh gaya belajar. Menurut Nasution (2009:37) Gaya belajar adalah cara yang konsisten yang dilakukan oleh seseorang dalam menangkap stimulus atau informasi, cara mengingat, berfikir dan memecahkan soal. Sedangkan menurut Bobby De Poter \& Mike Hernacki (2002:110) gaya belajar merupakan suatu kombinasi dari bagaimana ia menyerap dan kemudian mengatur serta mengolah informasi.

2. Gaya Belajar Mandiri

Konsep gaya belajar mandiri sebenarnya berakar dari konsep pendidikan orang dewasa. Namun demikian berdasarkan beberapa penelitian yang dilakukan oleh para ahli ternyata juga cocok untuk semua tingkatan usia. Menurut Thoha (1996:121) belajar mandiri adalah suatu otonom. Sikap kemandirian menunjukkan adanya konsistensi organisasi tingkah laku pada seseorang, sehingga tidak goyah, memiliki kepercayaan diri sendiri. Seseorang yang mempunyai sikap mandiri dapat secara tepat dan optimal serta tidak menggantungkan diri kepada orang lain. Menurut Steven Stein (2002:105) belajar mandiri merupakan kemampuan untuk mengerahkan dan mengendalikan diri sendiri dalam berfikir dan bertindak, serta tidak merasa bergantung pada orang lain secara emosional. Orang yang mandiri mengandalkan dirinya sendiri dalam merencanakan dan membuat keputusan.

\section{Tinjauan Pustaka}

1. Gaya Belajar 
3. Ciri - ciri Gaya Belajar Mandiri

Siswa yang mempunyai gaya belajar mandiri dapat dilihat dari kegiatan belajarnya. Siswa tidak perlu disuruh apabila belajar dan kegiatan belajar dilaksanakan atas inisiatif dirinya sendiri. Menurut Anton Sukarno (1989:64) menyebutkan ciri-ciri kemandirian belajar sebagai berikut:
a. Siswa merencanakan dan memilih kegiatan belajar sendiri.
b. Siswa berinisiatif dan memacu diri untuk belajar secara terus menerus.
c. Siswa dituntut bertanggunug jawab dalam belajar.
d. Adanya kecenderungan untuk berpendapat, berprilaku dan bertindak atas kehendaknya sendiri.

4. Aspek - aspek Gaya Belajar Mandiri

Menurut Suhaenah Suparno (2010:152) ada beberapa keterampilan belajar yang harus dimiliki oleh siswa agar dapat meningkatkan kemandirian dalam belajarnya, yaitu Mengenali diri sendiri, agar mampu memahami visi dan tidak keliru menafsirkan kemampuan dirinya sehingga tidak terlalu optimis maupun terlalu pesimis, Mempelajari cara belajar efektif, meskipun setiap gaya belajar siswa untuk belajar merupakan hal yang unik untuk dirinya dan mungkin sangat berbeda dengan gaya belajar orang lain serta Menumbuhkan motivasi instrinsik maupun ekstrinsik.

\section{Gaya Belajar Terbimbing}

Menurut Eggen (2012:177) belajar terbimbing adalah suatu metode pembelajaran dimana dalam proses belajar mengajar, guru memberi siswa contoh-contoh topik spesifik dan memandu siswa untuk memahami topik tersebut. metode gaya belajar ini merupakan suatu cara untuk memahami suatu topik. Fungsi pengajar disini bukan untuk menyelesaikan masalah bagi siswa, melainkan membuat siswa mampu menyelesaikan masalah itu sendiri. Sedangkan menurut Ruseffendi (2013:19), gaya belajar terbimbing merupakan suatu metode mengajar yang mengatur pengajaran sedemikian rupa sehingga siswa memperoleh pengetahuan yang sebelumnya tidak diketahui menjadi mengerti. Berdasarkan penjelasan di atas dapat disimpulkan bahwa penggunaan gaya belajar terbimbing, memungkinkan siswa dapat menemukan suatu masalah yang diberikan guru melalui keterlibatannya secara aktif dalam proses pembelajaran yang didasarkan pada pengalaman-pengalaman belajarnya. Keterlibatan secara aktif yang dimaksud adalah berupa kegiatan mengadakan percobaan atau penemuan sebelum membuat kesimpulan, manipulasi dan mentransfer informasi sehingga menemukan informasi baru berupa kebenaran.

\section{Karakteristik Gaya Belajar Terbimbing}

Pelaksanaan penggunaan gaya belajar terbimbing mempunyai karakteristik dalam proses pembelajaran pada siswa. Menurut Dessy (2010:31) menyatakan ada beberapa karakteristik yang perlu diperhatikan sebaga berikut:

a. Siswa mengembangkan kemampuan berpikir melalui observasi hingga membuat infersi atau generalisasi.

b. Sasarannya adalah mempelajari proses belajar kemudian menyusun generalisasi yang sesuai.

c. Guru mengkontrol bagian tertentu dari pembelajaran misalnya kejadian, data, materi dan berperan sebagai pemimpin kelas.

d. Guru memotivasi semua siswa untuk mengkomunikasikan hasil generalisasinya sehingga dapat dimanfaatkan oleh seluruh siswa. 


\section{Prestasi Belajar}

Menurut pendapat Hutabarat (1995:11) prestasi belajar adalah hasil usaha siswa yang dapat dicapai berupa penguasaan pengetahuan, kemampuan kebiasaan dan keterampilan serta sikap setelah mengikuti proses pembelajaran yang dapat dibuktikan dengan hasil tes. Prestasi belajar merupakan suatu hal yang dibutuhkan siswa untuk mengetahui kemampuan yang diperolehnya dari suatu kegiatan yang disebut belajar.

8. Faktor - faktor Prestasi Belajar

Prestasi belajar mempunyai hubungan erat dengan kegiatan belajar, banyak faktor yang mempengaruhi prestasi belajar baik yang berasal dari dalam individu itu sendiri maupun faktor yang berasal dari luar individu. Menurut Ngalim Purwanto (2010: 107), faktorfaktor yang mempengaruhi prestasi belajar adalah faktor dari dalam diri individu, faktor dari luar individu. Sejalan dengan pendapat tersebut, Muhibbin Syah (2011: 145) membagi faktor-faktor yang mempengaruhi belajar menjadi tiga macam, yaitu faktor internal, yang meliputi keadaan jasmani dan rohani siswa, faktor eksternal yang merupakan kondisi lingkungan di sekitar siswa dan faktor pendekatan belajar yang merupakan jenis upaya belajar siswa yang meliputi strategi dan metode yang digunakan siswa untuk melakukan kegiatan mempelajari materi-materi pelajaran.

\section{Pengukuran Prestasi Belajar}

Prestasi belajar merupakan hasil dari proses belajar yang berupa pengetahuan dan keterampilan yang dapat diukur dengan tes. Menurut pendapat Nana Sudjana (2005: 22) prestasi belajar terdiri dari tiga ranah yaitu:

a. Ranah kognitif, berkenaan dengan hasil belajar intelektual yang terdiri dari enam aspek yakni pengetahuan atau ingatan, pemahaman, aplikasi, analisis, sintesis dan evaluasi.

b. Ranah efektif, berkenaan dengan sikap nialai yang terdiri dari lima aspek, yaitu penerimaan, jawaban dan reaksi, penilaian, organisasi, internalisasi. Pengukuran ranah efektif tidak dapat dilakukan setiap saat karena perubahan tingkah laku siswa dapat berubah sewaktu-waktu.

c. Ranah psikomotorik, berkenaan dengan prestasi belajar keterampilan dan kemampuan bertindak. Pengukuran ranah psikomotorik dilakukan terhadap hasil-hasil belajar yang berupa penampilan.

10. Menggambar Dengan Perangkat Lunak

Menggambar dengan perangkat lunak adalah salah satu bidang ilmu utama yang dipelajari di dalam dunia teknik sipil. Bidang ilmu ini berisi tentang bagaimana mendata, menggambar dan mendesain suatu bangunan. Pada sekolah menengah kejuruan (SMK) kompetensi keahlian teknik gambar bangunan (TGB) mata pelajaran menggambar dengan perangkat lunak merupakan teori dan pengetahuan yang sifatnya pengantar bagi siswa untuk memahami tentang pengetahuan menggambar bangunan baik secara manual maupun dengan perangkat lunak (AutoCad).

\section{Metodologi Penelitian}

\section{Tempat dan Waktu Penelitian}

Penelitian ini dilakukan di SMK Negeri 6 Bekasi. Penelitian ini dilaksanakan pada bulan Agustus Tahun 2017.

\section{Metode Penelitian}

Dalam penelitian ini penulis menggunakan metode survey dengan desain deskriptif korelasional. Penelitian ini bersifat kuantitatif, dimana gejala-gejala yang akan diteliti diukur dengan 
menggunakan angka-angka. Dengan demikian penelitian ini memungkinkan digunakan teknik analisis statistik untuk mengolah data.

\section{Hasil Penelitian dan Pembahasan}

Pada tahap pertama, siswa dituntun untuk mempelajari dan memahami materi secara mandiri tanpa arahan dari guru, selanjutnya diadakan tes materi memahami sistem penggunaan toolbars. Pada tahap kedua, guru memberi arahan dan menjelaskan mengenai materi memahami sistem penggunaan toolbars, selanjutnya diadakan tes kembali untuk mengetahui adakah perubahan yang signifikan antara penggunaan gaya belajar mandiri dan gaya belajar terbimbing.

Tabel 1. Gaya Belajar

\begin{tabular}{ccc}
\hline & \multicolumn{2}{c}{ Gaya Belajar } \\
\cline { 2 - 3 } Rata-rata & 77,72 & 86,32 \\
Median & 75,5 & 86 \\
Modus & 71 & 88 \\
St. Deviasi & 8,97 & 5 \\
Nilai & 79 & 97 \\
Maksimum & & \\
Nilai Minimum & 64 & 76 \\
\hline
\end{tabular}

Berdasarkan di atas rata-rata nilai pada penggunaan gaya belajar mandiri 77,72 dengan nilai tertinggi 79 dan nilai terendah 64. Pada hasil penggunaan gaya belajar terbimbing diperoleh rata-rata 86,32 dengan nilai tertinggi 97 dan nilai terendah 76 . Terjadi peningkatan pada rata-rata, nilai minimum, dan nilai maksimum yang diperoleh. Hal ini menunjukkan bahwa penguasaan materi siswa pada penggunaan gaya belajar terbimbing semakin baik.

Selanjutnya data diolah menggunakan uji signifikansi koefisien regresi sederhana untuk mengetahui adanya pengaruh positif dan signifikan gaya belajar terhadap prestasi belajar mata pelajaran menggambar dengan perangkat lunak siswa kelas XI Teknik Gambar Bangunan di SMK Negeri 6 Bekasi. Berdasarkan perhitungan koefisien regresi diperoleh Fbitung $=3,530>$ Ftabel $=$ 1,677 pada taraf signifkan 0,05 (5\%). Dengan ini dapat diketahui terdapat pengaruh positif dan signifikan gaya belajar terhadap prestasi belajar mata pelajaran menggambar dengan perangkat lunak pada materi penggunaan sistem toolbars dalam penggambaran denah siswa kelas XI Teknik Gambar Bangunan di SMK Negeri 6 Bekasi.

\section{Kesimpulan, Implikasi dan Saran}

\section{Kesimpulan}

Berdasarkan hasil penelitian, yang telah dilakukan didapat beberapa kesimpulan yang dapat diambil antara lain:

1. Terdapat peningkatan prestasi belajar mata pelajaran menggambar dengan perangkat lunak pada materi penggunaan sistem toolbars dalam penggambaran denah siswa kelas XI Teknik Gambar Bangunan di SMK Negeri 6 Bekasi dengan rata - rata nilai 77,72 menjadi 86,32.

2. Terdapat pengaruh positif dan signifikan gaya belajar terhadap prestasi belajar mata pelajaran menggambar dengan perangkat lunak pada materi penggunaan sistem toolbars dalam penggambaran denah siswa kelas XI Teknik Gambar Bangunan di SMK Negeri 6 Bekasi.

\section{Implikasi}

Hasil penelitian yang menunjukkan bahwa terdapat pengaruh yang positif dan signifikan gaya belajar terhadap prestasi belajar mata pelajaran menggambar dengan perangkat lunak, mengandung implikasi bahwa untuk meningkatkan prestasi belajar mata pelajaran menggambar dengan perangkat lunak dapat dilakukan dengan 
mengajak siswa mengenali dan memahami gaya belajarnya dan mengoptimalkan gaya belajar tersebut semaksimal mungkin. Selain hal tersebut, untuk meningkatkan prestasi belajar mata pelajaran menggambar dengan perangkat lunak juga dilakukan dengan mengupayakan penggunaan gaya belajar siswa.

\section{Saran}

1. Selama proses belajar mengajar di kelas, siswa dituntut untuk selalu konsentrasi dalam mengikuti pelajaran dan tidak terpengaruh oleh keadaan di luar kelas. Siswa perlu mengenali gaya belajar yang dimiliki dan mengoptimalkan gaya belajarnya sehingga mampu menemukan metode belajar yang sesuai dengan diri siswa. Siswa seharusnya menyadari bahwa belajar dan mendapatkan prestasi belajar yang tinggi adalah tanggung jawab siswa, sedangkan guru atau faktor eksternal yang lain hanya sebagai fasilitator yang membantu siswa dalam mencapai prestasi belajar.

2. Setiap guru diharapkan untuk mengajak siswanya untuk mengenali dan memahami gaya belajar yang dimiliki oleh masing-masing siswa dan mengajarkan siswanya untuk memberdayakan gaya belajar tersebut semaksimal mungkin. Guru harus menyesuaikan gaya mengajarnya sesuai dengan gaya belajar siswa. Guru dituntut untuk menggunakan berbagai metode pembelajaran sehingga mampu mengkoordinir tiap-tiap gaya belajar yang dimiliki siswanya. Selain itu pemahaman guru atas gaya belajar siswa diharapkan mampu membuat guru untuk memberikan keleluasaan bagi siswa untuk menyerap informasi atau memahami suatu pelajaran dengan caranya sendiri sesuai dengan gaya belajarnya.

3. Penelitian ini memberikan informasi bahwa faktor gaya belajar berpengaruh terhadap prestasi belajar menggambar dengan perangkat lunak pada materi penggunaan sistem toolbars dalam penggambaran denah sebesar 86,32. Hasil tersebut menunjukkan prestasi belajar menggambar dengan perangkat lunak masih dipengaruhi oleh variabel lain, diharapkan dalam penelitian selanjutnya untuk mengetahui faktor faktor yang mempengaruhi prestasi belajar menggambar dengan perangkat lunak selain yang diteliti dalam penelitian ini.

\section{Daftar Pustaka}

Anton, Sukarno. 1989. 'Perbedaan Keefektifan Sistem Buku Pegangan Kuliah Ditinjau Dari Bakat, Sikap Mandiri, Persepsi Kualitas Pengajaran pada Mahasiswa Jurusan Ilmu Pendidikan FKIP UNS”. Tesis. Jakarta : PT.Indeks

B. Uno, Hamzah. 2008. Teori Motivasi dan Pengukurannya, Jakarta : Bumi Aksara.

Eggen, Paul. 2012. Strategi dan Model Pembelajaran Mengejar Konten dan Ketermpilan Berfikir. Jakarta: Indeks.

Nasution. 2009. Berbagai Pendekatan Dalam Proses Belajar dan Mengajar, Jakarta: PT.Bumi Aksara.

Nur, Syam. 1999. Pengantar Filsafat Pendidikan. Malang: FIP FKIP

Purwanto, Ngalim. 2010. Psikologi Pendidikan, Bandung: PT. Remaja Rosdakarya.

Ruseffendi. 2013. Dasar-Dasar Penelitian Pendidikan dan Bidang NonEksakta Lainnya. Bandung: Tarsito.

Sudjana, Nana. 2005. Penilaian Hasil Proses Belajar Mengajar, Bandung: PT. Remaja Rosdikarya.

Suparno, Suhaenah. 2010. Membangun Kompetensi Belajar. Direktorat jendral. Pendidikan Tinggi Dapartemen Pendidikan Nasional.

Syah, Muhibbin. 2011. Psikologi Belajar, Jakarta: PT. Raja Grafindo Persada.

Thoha, Cabib. Self-directed Learning, Yogyakarta: Pustaka Pelajar, 1996 
Jurnal Pendidikan Teknik Sipil 